\title{
Steroid Assays in Paediatric Endocrinology
}

\author{
John W. Honour \\ University College London Hospitals, London, England
}

\begin{abstract}
Most steroid disorders of the adrenal cortex come to clinical attention in childhood and in order to investigate these problems, there are many challenges to the laboratory which need to be appreciated to a certain extent by clinicians. The analysis of sex steroids in biological fluids from neonates, over adrenarche and puberty present challenges of specificities and concentrations often in small sample sizes. Different reference ranges are also needed for interpretations. For around 40 years, quantitative assays for the steroids and their regulatory peptide hormones have been possible using immunoassay techniques. Problems are recognised and this review aims to summarise the benefits and failings of immunoassays and introduce where tandem mass spectrometry is anticipated to meet the clinical needs for steroid analysis in paediatric endocrine investigations. It is important to keep a dialogue between clinicians and the laboratory, especially when any laboratory result does not make sense in the clinical investigation.

Key words: Steroid,adrenal, adrenal tests assay
\end{abstract}

Received: $03.02 .2010 \quad$ Accepted: 25.02.2010

\section{Introduction}

The analysis of steroids for investigations in paediatric endocrinology is a challenge for the laboratory. There are many developmental events and pathological disorders to be considered in providing such a service. The laboratory must also be on the look out for anomalous results as well as keep abreast of new analytical developments that may improve the service. The specificity of a steroid assay for one analyte is often not assured within a patient sample. In practice, a result cannot be transferred with the patient if investigations move from one centre to another because of assay variabilities. These factors are attributed to interferences and inaccuracies probably through the differences in the antibodies used in the assays, also lack of standardisation of reagents and standards. These are now issues being addressed particularly for testosterone (1-4). Certified reference materials in USA and Europe (native samples with defined hormone concentrations) have been available for many years as targets for hormone accuracy, but have not been widely used. Immunoassays for peptide hormones are prone to interferences from auto-antibodies and antibodies that react with reagents (heterophilic antibodies-mouse antibodies in patient samples that react with monoclonal reagent antibodies). In some (sandwich) assays, mainly for peptide hormones, false low results are due to high-dose hook effects. These issues will not be covered in the present review but have been addressed recently (5). Paper chromatography, thin layer chromatography (TLC) on silica and alumina, gas chromatography (GC) and high performance liquid chromatography (HPLC) have all been applied to the analysis of steroids in extracts of biological fluids, but only GC and HPLC are in routine hospital use and will thus be covered in some detail here.

\section{Address for Correspondence}

John W Honour, Clinical Biochemistry, University College London Hospitals, London, W1T 4EU, England

Cell: +44 7710901800 E-mail: john.honour@uclh.nhs.uk

(c) Journal of Clinical Research in Pediatric Endocrinology, Published by Galenos Publishing. 
Reference methods for certain hormones have been available in highly specialised centres. For steroids, those reference methods have relied upon stable-isotope dilution analyses with GC coupled with mass spectrometry (MS) (6-8). The dual selectivity of the separation of a mixture of components and specific ion detection enables exceptionally high accuracy without interferences (9-13). Some immunoassays have approached that level of accuracy, but only when the method includes extraction and chromatographic purification, again limited to very specialised laboratories $(14,15)$. A number of novel mass spectrometric techniques (fast atom bombardment, for example) looked to have the potential for more general analytical use (16), but did not stand up to rigorous clinical use and needed highly skilled operators. Tandem MS now looks to truly have the potential to improve the quality of assays needed in clinical practice.

Reference intervals are essential for interpretation of test results. The derivation of these ranges is difficult and expensive and complicated in normal children by issues of consent and insufficient numbers for statistical analysis. Samples from the outpatient paediatric population and hospitalised patients without endocrine disease (surgical patients) are numerous and are a useful mechanism to overcome supply of reference materials $(17,18)$.

\section{Background}

\section{Technology}

Colorimetric assays for steroids were the first chemical means for the quantitative analysis of steroids, replacing bio-assays that had little use in paediatrics because of low hormone concentrations and the large sample volumes needed to get a measurable effect. Porter-Silber chromogens are formed when the dihydroxyacetone side-chain of 17-hydroxycorticosteroids (cortisol) react with phenylhydrazine. The Zimmerman reaction involves reaction of 17-ketosteroids (androgens) with dinitrobenzene. These tests also were not specific enough for clinical paediatric use and have largely become obsolete apart from a few countries, mostly outside Europe. In routine clinical practice, immunoassays have provided much valuable information and will continue to be used. Radioimmunoassays have been largely replaced with alternative labels. There are many problems with assay specificity. In any automated method in the laboratory, where parts of the equipment perform repeated steps in the process, there can be problems with sample carry-over when a sample containing high concentrations of the analyte precedes a sample with low concentration. Mass spectrometric techniques have much promise and there will be changes in endocrine laboratory services. New reference ranges will be needed and this will be a challenge for paediatric laboratories. Bioassays have been introduced using cell preparations, which enable more reproducible results than the classic experiments to assess biological activity of extracts when tested, for example, in adrenalectomised rats or immature animal. These novel assays are not yet in use routinely, but have a place in some investigations that will be considered later in this review.

MS is widely used in clinical chemistry and the applications can be appreciated with some understanding of the mechanics of the component parts. The analytes can be drugs, steroids, amino acids and organic acids as small molecules. Newborn screening is an area, where MS has brought major advances (19). There are some basic features of MS and a number of terms will be encountered when reading about the technology. Chromatographic separation is often coupled with MS detection and this is called a hyphenated method. The components of the sample after separation in gas or liquid chromatography are introduced into the vacuum of the mass spectrometer. MS is a technique in analytical chemistry based on measuring chemicals as ions in the gaseous state according to their weights (strictly speaking, according to mass and charge ratio $[\mathrm{m} / \mathrm{z}])$. MS analyses charged particles. A mass spectrometer can be divided into a sample inlet, source, analyser and detector, all controlled by a computer (Figure 1). The mass spectrometer produces ions in the source from molecules in a gas or handles ions delivered in a gas or spray to the MS. In the ionisation process, fragment ions may also be produced. All mass spectrometers operate at high vacuum to minimise ion-molecule reactions, scattering and neutralisation of ions. After ions are formed in the source, they are accelerated into the mass analyser. Once the ions enter the analyser, they are usually sorted in an electrical field or on the time to pass to the detector (time of flight analyzer). The quadrupole mass spectrometer is probably among the commonest

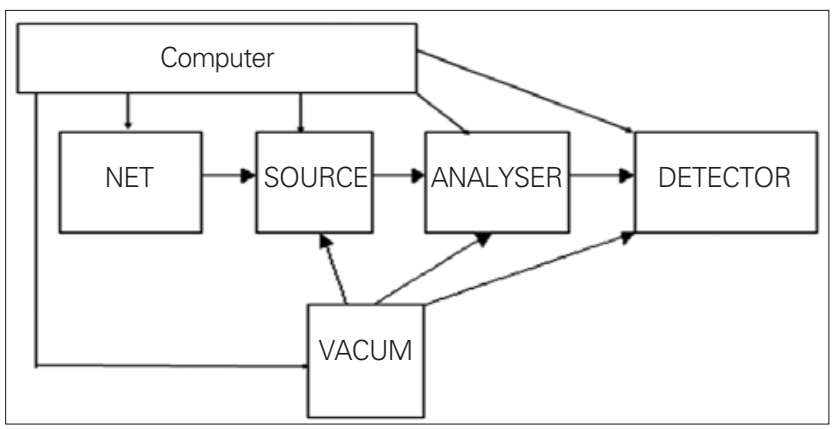

Figure 1. Schematic layout of a mass spectrometer. In tandem mass spectrometry (MS) the analyser would in principle comprise three analysers (quadrupoles), the middle unit being a collision cell. An ion focussed in the first MS would be fragmented in the collision cell. In the third MS daughter ions would then be focussed to the detector 
instrument designs now being used in clinical work, although ion traps have high sensitivity. The quadrupole analyser consists of four rods. Rods operate in opposite pairs and each carries an Rf voltage. Only ions of the proper $\mathrm{m} / \mathrm{z}$ value can successfully traverse the entire filter to reach the detector. Other ions are drawn into the rods. When scanning over a mass range, the DC potential is varied linearly with the Rf/DC ratio held constant and an entire spectrum is obtained.

The mass analyser separates ions, either in space or in time, according to their mass to charge ratios. After the ions are separated, they are detected and data transferred to the computer for analysis. Most mass spectrometers use a photomultiplier detector tube. Data analysis includes plotting spectra, background subtraction facility, library search and chemical formula development, processing of quantitative data. Several spectra can be taken per second. Quadrupoles cover a wide mass range (typically up to 1,000 Daltons) that is in essence extendable when looking at multiply charged particles that have mass to charge ratios within a lower range than the molecular weights. Many compounds will have the same nominal or integral mass and will not be distinguished by the usual low resolution mass spectrometers. Resolution is defined according to the mass of the molecules separated by a valley, and is a function of mass and the difference between the 2 accurate masses.

A mass spectrum shows the intensities of the range of ions ( $\mathrm{m} / \mathrm{z} 50$ to 900 is a typical range) from an analyte and is a qualitative fingerprint of the molecule. Accurate quantitative analysis is possible with MS and some regard the technique as a reference method, though this may not always be the case. The acquisition of an MS can be justified by many laboratories through cost savings largely from lower reagent costs. In order for mass spectrometry to be effective, within the organisation of a clinical laboratory, a minimal analysis time and effort in sample preparation was a key element.

The accuracies of steroid methods are variable and results sometimes not clinically sound for all of these components, particularly for low concentrations of certain steroids in children (20-25). There is now a need to move to accurate methodology fit for clinical purpose. There will be a need for change in laboratory practices and external quailty assurance (EQA) must move away from the traditional approach of matching results with a peer group and ignoring the differences between methods $(1,26)$. Laboratories have to consider other factors such as sample carry-over in automated methods (27). There is a need for systematic reviews of tests in relation to diagnostic need (28) this has been started for steroid assays (29).

\section{Samples}

Blood, saliva and urine are fluids available for steroid analysis. It is important to consider the information that is available from different tests. Each method requires reference range appropriate to the development of the child and related diagnostic significance (30). Steroids in blood are largely bound to proteins (albumin and specific proteins such as sex hormone-binding globulin (SHBG)). The free steroid in blood is filtered at the salivary gland and kidney, and steroid concentrations in saliva and urine correlate with free hormone in blood. In the investigations of thyroid function, there are many methods that quantify free hormone concentrations in plasma. That has not been widely used in the steroid field. Assays for steroids after equilibrium dialysis or ultrafiltration have been described for cortisol (31). Free testosterone can be determined by analogue methods (32), ammonium sulphate precipitation (33), dialysis and ultrafiltration. Five routine assays have been compared with a GC-MS method based on ultrafiltration (34). The methods are not amenable to automation and were not considered important in an Endocrine Society review of testosterone determinations $(1,35)$. Indices of free hormone are used by some, based on a percentage of the total steroid that can be bound to a concentration of the specific binding protein, i.e. free androgen index

$\mathrm{FAI}=$ (serum testosterone/SHBG concentration) X100

Two assays are needed, both of which are subject to error, particularly in prepubertal boys, when testosterone is $<5 \mathrm{nmol} / \mathrm{L}$ and SHBG above $120 \mathrm{nmol} / \mathrm{L}$.

Blood samples can have large changes in steroid concentrations over a $24^{\mathrm{h}}$ period and timing can be critical, so the laboratory need to be informed of time of collection of any sample to assist interpretation of results. Plasma cortisol can be $200-800 \mathrm{nmol} / \mathrm{L}$ around $0800^{\mathrm{h}}$ and less than $150 \mathrm{nmol} / \mathrm{L}$ at midnight. This is often depicted as a sine wave curve to illustrate a diurnal rhythm. In fact, there is a strong pulsatile pattern during the night with 3 or 4 peaks of increasing intensity starting around $0200^{\mathrm{h}}$ to $0300 \mathrm{~h}$ with a final peak between $0600^{\mathrm{h}}$ and $1000^{\mathrm{h}}$ (36). Antenatal dexamethasone administration in pregnancies at risk of preterm delivery is an established procedure to decrease neonatal mortality. This can affect the hypothalamicpituitary-adrenal axis in the neonate and influence hormone tests (37). Whoever collects samples should check laboratory guidelines for sample size and container, because material in the containers and separating agents and preservatives can affect assay performances (38). It may not always be possible to get a sample sufficient for all the tests wanted, so a priority should be discussed with the laboratory to optimise use of sample. Laboratories need to preserve samples in the state they left the body, so separation of plasma from blood cells in a timely manner and suitable storage around freezing temperatures or below need to be observed and monitored (39-41). 
Saliva samples have some attraction for paediatric investigations, because collection is less invasive $(42,43$ and 44 for reviews). There are a number of techniques to improve saliva flow (45). Like urine, saliva steroids reflect the free hormones in the blood. The steroids concentrations are thus normally very low (cortisol around $5 \mathrm{nmol} / \mathrm{L}$ ) and sensitive assays are needed. 11-Hydroxysteroid dehydrogenase activity (HSD11B1) is active in salivary glands, so saliva has high concentrations of cortisone and a cortisol assay must be used that does not detect cortisone as well (46). The loss of diurnal rhythm of cortisol can be detected in screening for Cushing's syndrome (47-49). Saliva samples can be taken for analysis of 17-hydroxyprogesterone (17-OHP) or androstenedione (AS) to monitor congenital adrenal hyperplasia $(\mathrm{CAH})$ treatment $(50,51)$. Because of the variations in steroid production and low concentrations of steroids in blood and saliva, urine has been a useful biological fluid for analysis.

Free cortisol excretion rate in urine can be determined. This is an important index of cortisol excess, but should never be used to demonstrate adrenal suppression. Immunoassays for cortisol in urine are not specific, being subject to cross reaction from cortisone (52) and steroid metabolites $(53,54)$. Steroids are inactivated in the liver through a number of reductive enzyme catalysed reactions and metabolites are conjugated with glucuronic and sulphuric acid to aid urinary excretion. In the neonate and for the first six months of life, there are a number of active enzymes (hydoxylases at carbons 1,6,15,18), which adds to the number of steroids requiring identification in normal and pathological states. From a $24^{\mathrm{h}}$ collection, the combined excretion rates of corticosteroid metabolites come close to production rates. In young children, a $24^{\text {h }}$ collection is difficult to obtain reliably, for much diagnostic work analysis of steroids in a spot sample gives useful information. Some laboratories are able to accept disposable diapers (free of any faecal soiling) for certain analyses (55). Urine can be obtained by squeezing, pressing (hydraulic or wine press) or centrifugation (fruit juice extractor).

In paediatrics, there are wide changes in reference ranges for age, gender and stage of development that influence the mix of steroids present in the sample. There are problems with samples from preterm babies and neonates (interferences from adrenal fetal zone steroids), adrenarche (increase in adrenal androgen secretion) and puberty (changes in concentrations of binding proteins, as well as pituitary and gonadal hormones). Furthermore, when providing assays for the range of clinical conditions, then results are encountered that fall outside the range of assay calibration. Samples then need to be diluted. Ideally, the matrix needs to be preserved, so use of the assay zero standard is the best way to achieve this without altering the dynamics of the assay. Many publications attest to the difficulties created clinically from misinterpretation of steroid results (see \# 56 for 2 examples around testosterone assays).

\section{Immunoassays of Steroids}

In the 1960's, immunoassay revolutionised the clinical laboratory services for hormones (57). The low concentrations in children of certain steroids often meant larger samples were needed to achieve sensitivity in the assays. An extraction and concentration step was needed in some cases (58). In order to reduce total sample size for paediatric samples, especially when several tests were needed, some laboratories developed chromatographic separation of a single sample extract before immunoassays of the separate components-an extremely demanding and time-consuming approach $(14,15,59-64)$. Some automation of the procedure is possible (65). Specificity of steroid assays is also improved by chromatography before immunoassay (for example paper chromatography (66) or column chromatography with celite (67-69) Kieselguhr (70) or using Sephadex LH-20 (71) or Lipidex, a lipophilic derivative of Sephadex $(72,73)$. Since steroids are largely bound to proteins, it is usual to measure the concentration of the total hormone in plasma after displacement of the steroid by extreme $\mathrm{pH}$, heating or addition of a synthetic steroid.

Immunoassays have evolved over the years (74). Initially, assays were set up in-house using reagents that were generated by the laboratory, or obtained from other laboratories or purchased from commercial sources. The key components were a standard to generate a graph of signals from the range of hormone concentrations (calibration curve), an antibody and a label. Antibodies were initially created by injection of mice, rabbits or sheep with a hapten. For steroids, it is necessary to couple the steroid to a protein, such as bovine serum albumin of limpet haemocyanin, to create a significant hapten. Specificity was improved by affecting the union of steroid to protein at a position in the steroid remote from the functional groups. After several injections of the hapten, high antibody titres were generated and serum from the animals could be diluted to give large volumes of the assay-ready antibody preparation. As specificity of the antibody recognition of a steroid improved, then confidence was gained to use biological samples directly in the assay tube. Prior to that time, steroids were extracted into an organic solvent that was dried and reconstituted in assay buffer for the analysis. The extraction step was certainly important to separate for neonatal samples, in which the presence of fetal adrenal zone steroid sulphates needed to be stripped from free steroids in the samples, so as to reduce to interference in 
the immunoassay (see Figure 2 from reference 75 for an illustration of the lowering of 17-OHP results in an assay based on solvent extracts compared with plasma itself). In some cases, steroids in the organic extract were purified by chromatography (76) and the eluates from an HPLC could be collected in timed fractions (77).

At the outset, carbon-14 and tritium labelled steroids were commonly used and liquid scintillation counting was required for detection of beta-radiation. The label was usually present in the assay tube at a concentration to react with around $50 \%$ of the binding sites on the antibodies. Addition of steroid in the sample thus reduced the amount of bound label (competitive immunoassay). After the reaction of analyte and label with the antibody, the free and antibody fractions had to be distinguished. The free fraction could be absorbed from the sample with charcoal that could then be precipitated with the aid of centrifugation. Waste disposal was a big problem, so gamma ray emitting isotopes (iodine 125, for example) were attractive, although they had short half lives, so reagent had to be renewed on a regular basis. To introduce iodine, labelling of a steroid usually requires the use of a derivative of the steroid that will react with iodine. Tyrosine and histamine conjugates of steroids have been common substituents for this purpose, but this then makes the label structurally different from the natural steroid in a biological sample, so the compounds react differently with the antisera (78). Multi-well gamma counters helped with rapid batch processing of 10 or 16 samples at a time. The antibody-bound fraction could be precipitated after the addition of a second antibody (donkey antisera to the mouse, rabbit or sheep protein), that increased the molecular size of the complex. Later techniques were developed to bind the antibody to the wall of a reaction tube (coated tube) or to particles (beads or magnetic particles); the free fraction in solution could then be decanted at the end of the reaction.

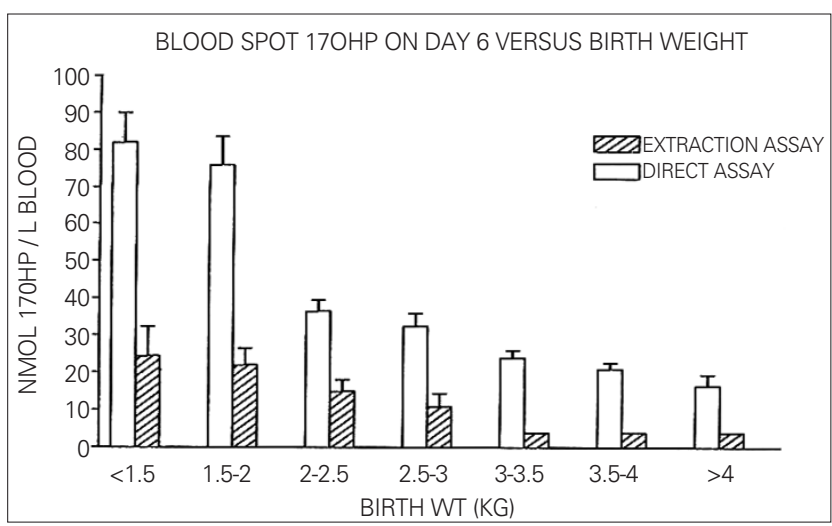

Figure 2. Direct assays for 17-hydroxyprogesterone (17-OHP) give higher results than when a solvent extract of a sample is analysed. Interferences in the assay from fetal adrenal steroid sulphates are removed by the extraction from reference 75 , with permission
Commercial kits for 17-OHP typically are designed to detect elevated concentrations in heterozygotes for classical disease and patients with non-classic forms-a worthwhile test in the investigation of patients with androgen excess and infertility. Kits, however, to detect the classical form of the disease would not be economically viable. Interferences in 17-OHP assays can be encountered in the newborn period often from the fetal adrenal zone steroids (DHAS, pregenenolone) (79). In patients with $\mathrm{CAH}$ due to 21 and 11-hydroxylase deficiency, the high concentrations of cortisol precursors can lead to falsely elevated results for cortisol $(80,81)$.

Monoclonal antibodies were successfully generated for many analytes, but for steroids they did not initially prove to be as good as the polyclonal animal raised antibodies. Now, monoclonal antibodies are attractive, because the supply of a characterised antibody can be sustained (82-84). Some changes in hapten have assisted antibody quality (85). A few methods are based around anti-idiotype assays $(86,87)$. Since mice are used for monoclonal experiments, samples from patients exposed to mice (or treated with mouse monoclonal antibody therapies) can introduce heterophilic antibody reactions (88). Unusually low results for steroids can be found (89) and appropriate steps need to be taken to counteract the heterophilic antibodies $(90,91)$. To overcome concerns over safety and stability of reagents, alternative labels were introduced (chemiluminescent, fluorescent, as examples) (92), and from that time automation gradually took over (reviewed by Wheeler \# 93). With the introduction of multi-channel automated analysers, it became possible for the laboratory to analyse all the components for results of a panel of hormones (cortisol, progesterone, oestradiol, testosterone, T3, free T4, DHAS, LH, FSH, TSH, prolactin, ACTH) in one sample over a few hours. Multi-channel, automated methods really needed to have the same incubation steps for each analyte and inevitably optimisation for certain assays had to be sacrificed. In general, steroid assays take longer times to reach equilibrium than peptide assays.

Automated immunoassay systems have been evaluated in the paediatric setting and found to be acceptable (94-96). Problems have inevitably been encountered with automated methods in the laboratory. In immunoassays, results for testosterone in newborns have been reported to be grossly elevated (20) due to interferences from fetal and placental steroids. One publication reported that, when samples were tested for testosterone after the same sample had just been tested for oestradiol (97), high concentrations of testosterone were indicated. This was explained by carry-over of reagents in the sample probe, rather than sample, because direct steroid assays need to 
incorporate a means to displace steroid from binding proteins (for example, testosterone in the oestradiol assay). Such problems are not easy to resolve, because the formulation of assays is not described in detail by the instrument manufacturers. The information on cross reactivity is another area where kit information may not be entirely valid. Ideally, a displacement curve should be plotted for any potential interfering compound. Cross reactivity is then expressed from the $50 \%$ binding concentration of the interferent relative to the concentration of the analyte at that point in the calibration curve (then usually expressed as a percentage cross-reaction). Many kit manufacturers take an approach of adding a concentration of the interferent that is assumed to be greater than ever encountered in biological samples and assessing the concentration measured as a percentage of the amount added. DHAS can cross react in the testosterone assay on the Abbott Architect (98).

A metabolite of an interferent can be more potent in the immunological reaction and create a falsely high result. Metabolites are not always available and indirect evidence is needed to support proof. For instance, in an androstenedione assay, elevated concentrations can be apparent in samples collected from patients taking spironolactone. The cross reactivity was reported to be less than $0.01 \%$, but androstenedione returned to the normal range when treatment was withdrawn, suggesting interference, probably from the metabolites rather than the drug itself (Honour and Dawnay, unpublished) (see Table 1). Low concentrations of steroids are difficult to assay. Direct immunoassays are not sufficiently accurate and specific for oestradiol in children (23) or androgens in the investigation of disorders of sexual development $(56,99,100)$.

\section{Gas Chromatography}

Although many investigations have relied upon analysis of steroids in blood samples, the analysis of urinary steroids by GC has proved to be a very powerful tool with the ability to recognise most of the steroid disorders in children from characteristic steroid profiles (metabolomes) $(101,102)$. In fact, many of the recently discovered disorders of the adrenal cortex can be credited to this technique pioneered in 1970 by Cedric Shackelton, who has ever since made seminal contributions to this diagnostic area (see Table 2 for summary of these achievements). Steroids need to be extracted from urine; solid phase extraction is commonly used for this. Steroid conjugates are hydrolysed using glucuronidase and sulphatase enzyme preparation. After re-extraction of steroids, methyloxime-trimethylsilyl ether derivatives are formed. These make the steroids stable for high temperature GC separation and direct fragmentation in the MS. Steroids eluting from a GC column can be detected non-selectively by a flame ionisation detector, the identification is by retention time. If the effluent is directed to a mass spectrometer, then hundreds of spectra can be taken from mass to charge 50 to 1000 over a 30 minute GC run. Each spectrum is a fingerprint of the steroid. For the detection of gross changes in steroid production, a spot sample of urine can provide enough information in a steroid profile from whether individual and groups of steroids are low, normal or raised. In $\mathrm{CAH}$, there will be low levels of cortisol metabolites, raised concentrations of intermediates (such as 17-OHP metabolites), and low or raised androgens, depending on the affected enzyme. As a result of the pattern of high cortisol production during the night, the highest urinary excretion rates of the cortisol metabolites is

Table 1. Endocrine results in patient with polycystic ovary syndrome before and on treatment with spironolactone

\begin{tabular}{|c|c|c|c|c|c|}
\hline & LH & FSH & Testosterone & DHAS & AS \\
\hline \multicolumn{6}{|c|}{ PRE-TREATMENT } \\
\hline 1 & 13.9 & 6.6 & 5.2 & 7.5 & 9.5 \\
\hline 2 & 19.5 & 7.9 & 7.9 & 6.0 & 16.1 \\
\hline 3 & 42.4 & 12.4 & 1.6 & 2.7 & 11.8 \\
\hline 4 & 11.6 & 5.0 & 3.3 & 8.9 & 7.9 \\
\hline 5 & 4.5 & 5.2 & 1.5 & 5.7 & 6.5 \\
\hline \multicolumn{6}{|c|}{ ON-TREATMENT } \\
\hline 1 & 16.3 & 7.8 & 6.3 & 7.2 & 37.5 \\
\hline 2 & 19.7 & 8.3 & 8.3 & & 23.0 \\
\hline 3 & 33.2 & 4.3 & 4.9 & 8.5 & 98.1 \\
\hline 4 & 6.7 & 5.7 & 3.7 & 3.6 & 47.6 \\
\hline 5 & 4.4 & 8.3 & 1.4 & 2.8 & 30.5 \\
\hline
\end{tabular}


between $1000^{\text {h }}$ and $1800^{\text {h }}$ (103), so it is not wise to collect spot samples in the early morning or afternoon for assessment of cortisol production on this basis. Ratios of metabolites are diagnostic of 5-alpha reductase deficiency and defects of HSD11B1 (high cortisone) and HSD11B2 (high cortisol).

In order for steroids in plasma to be detected in GC methods, it was necessary to make derivatives that were suitable for sensitive electron capture detection. This was a difficult detector to keep for routine use and will not be considered here. GC-MS has been found also to be a very reliable quantitative method for steroids in plasma such as DHAS, 17-OHP, AS, testosterone, 17-hydroxpregnenolone, 11-deoxycortisol and DHAS (7-13). It is superior to other methods, because of the improved specificity of assays through separation of steroids in the sample extract, which is needed particularly for tests on newborn infants. A deuterium labelled internal standard steroid of high purity is used for what is effectively an isotope dilution analysis. The internal standard is added at the start of the assay, so acts as a recovery marker for the extraction and chromatography. Heptafluorobutyrate derivatives are most used, because of their ease of preparation and minimal fragmentation in the mass spectrometer. After GC separation, the steroids are fragmented usually by electron impact, and ions for the analyte and the internal standard are monitored by the MS. Specificity in the assay can be demonstrated from the relative responses for a quantifier and a qualifier ion for each compound. Calibration curves are linear for low concentrations through normal levels to grossly pathological levels in patients with $\mathrm{CAH}$, where levels up to $1000 \mathrm{nmol} / \mathrm{L}$ can be seen. There is $97-103 \%$ recovery of steroid added to samples across a wide range of concentrations. Comparison of results with a number of clinical samples assayed by a direct and an extracted RIA showed close agreement with extracted RIA's. Most laboratories will not measure 17-OHP in the first 3 days after birth because of false high results due to interference from fetal adrenal zone steroids like 17-hydroxypregnenolone and its sulphate (79). The GC-MS method is not subject to these interferences and reliable results can be obtained in affected children within $12 \mathrm{~h}$ of birth. Internal QC shows low CV's compared with immunoassay methods. In external EQA, the GC-MS method performances have also been impressive with CV's less than 3\%. Only 500 microlitres of sample is normally used but when necessary 50 microlitre sample can be used without compromising a result. Normal ranges at different ages and genders are available, as well as reference ranges for Synacthen tests. These values are different to results from immunoassays. This assay has been compared with MS/MS, but the GC/MS has a very

Table 2. Applications of urinary steroid profile analysis by GC-MS

1. Inborn errors of steroid metabolism. These include

(A) Congenital adrenal hyperplasia (CAH) due to deficiency of:

- Pregenenolone synthesis resulting from StAR protein defect in cholesterol uptake or, more rarely, cholesterol side chain cleavage enzyme (CYP11A1) defect (lipoid adrenal hyperplasia)

-3ß-hydroxysteroid dehydrogenase (HSD3B2)

-17 $\alpha$-hydroxylase (CYP 17)

-11ß-hydroxylase (CYP 11B1)

-21-hydroxylase (CYP 21A2)

- Cytochrome P450 oxidoreductase (POR, associated with Antley-Bixler syndrome)

-11-hydroxysteroid dehydrogenase I (HSD 11B1, cortisone reductase, usually apparent, due to an intronic mutation combined with a hexose 6 phosphate dehydrogenase mutation)

- 7-Dehydrocholesterol reductase (DHCR7, associated with Smith Lemli Opitz syndrome, SLOS)

- glucocorticoid receptor action

(B) Deficiency of

- 5 $\alpha$-reductase (SRD5A2)

- steroid sulphatase (STS)

- aldosterone synthase (CYP 11B2)

- aromatase (CYP19)

-11-hydroxysteroid dehydrogenase II (HSD 11B2, apparent mineralocorticoid excess, AME)

2. Steroid-secreting tumours

3. Steroid resistance

4. Adrenocortical hyper- and hypofunction

5. Changed steroid metabolism due to drug treatment (eg metyrapone, ketoconazole) or to clinical condition (eg Cushing's syndrome, anorexia nervosa) 
high standard to beat. Any child with ambiguous genitalia at birth needs a 17-OHP result as soon as possible; this method meets the criteria, with results less than $3 \mathrm{nmol} / \mathrm{L}$ in normal infants from the first day of life, and clearly elevated above $100 \mathrm{nmol} / \mathrm{L}$ in a child with 21-hydroxylase deficiency.

Just as profiles of steroids by GC and GC-MS reveal information to recognize abnormal patterns with adrenal disorders then GC-MS-MS provides additional information. GC-MS-MS in product ion scan mode enables the recognition of most steroids in the sample through the combination of retention time and fingerprint of the mass spectrum. The nature of unknowns can also be approximated (104). GC coupled with tandem mass spectrometry (GC-MS-MS) (MS1 selecting ions, MS2 scanning fragments) can give even greater power to identification of steroids. Recently, more than 120 steroids were characterised in the urine of patients with $\mathrm{CAH}$ due to 21-hydroxlase deficiency (104). The sum of glucocorticoid metabolites in urine (TCM) collected for $24^{\mathrm{h}}$ approximates the daily production rate of $(105,106)$ and is an excellent test for adrenal suppression (107). The improved sensitivity of LC-MS-MS methods shown for androgens and oestrogens (to $<10$ pmol.L) will now allow earlier and more accurate assessments of pubertal development (108). Even before signs of puberty, girls had higher androgen and oestrogen levels than boys.

\section{Liquid Chromatography}

Steroids can be separated by reverse phase HPLC and detected with UV spectroscopy for some diagnostic work (76,109-115). In reverse phase chromatography, a typical elution order will be aldosterone, cortisol, DHAS, corticosterone, 11-deoxycortisol, AS, testosterone, DHA, 17-OHP and progesterone. This approach is only successful, when sample concentrations of the steroids are in excess of 200 $\mathrm{nmol} / \mathrm{L}$-i.e. for cortisol and DHAS under normal circumstances and raised concentrations of intermediates in patients with disorders of cortisol synthesis. Sample processing is minimal and results can be available within hours of sample receipt in the laboratory.

In LC-MS, the effluent from HPLC is directed through a capillary to the source of the mass spectrometer. The temperature of the capillary is adjusted to a level, where the solvent is partially vaporized (Thermospray). This generates a supersonic jet of vapour that contains a mist of electrically charged particles. The ion chamber is evacuated and solvent continues to leave the droplets concentrating charge at the surface. Eventually, ions are expelled and leave the thermospray source through a small orifice in the sampling cone. Ammonium acetate is often incorporated into LC solvent systems to accelerate the ionisation process here.
Cortisol, being in blood at 200 to $800 \mathrm{nmol} / \mathrm{L}$ as opposed to $17-\mathrm{OHP}$ around $5 \mathrm{nmol} / \mathrm{L}$, can be measured by LC/MS without the lengthy sample work-up and derivative formation needed in a GC-MS method. This methodology has also been used to establish the production rate of cortisol. Previously, radioactive methods had been used giving results around 18 milligrams per day (116). Clinicians were comfortable with that, because replacement treatment is usually at around that level, but no treatment regimen yet replaces the normal pattern of cortisol concentrations in blood over the 24 hours. When stable isotope dilution methods were used, cortisol production rate is 6 to 9 milligrams per metre squared with most secretion between 0200 and $0800^{\text {h }}(117)$ as expected from blood concentrations when samples are taken at 10 minute intervals. Stable isotope dilution LC-MS has been used for 17-OHP in plasma (118).

Fast atom bombardment in the mass spectrometer was a technique of great promise some years ago, but did not get widely adopted and is rarely used today. A steroid extract could be dissolved in glycerol and put on the whiskers of a probe where the sample was desorbed and ionised by being bombarded with fast Xenon or caesium ions. Steroid conjugates did not need to be hydrolysed and mass spectral patterns were obtained of individual steroid (119). Abnormal results were seen for glucuronide conjugated steroids in $\mathrm{CAH}$ (16). When pregnancy urine was analysed by FAB MS, the profile from a normal pregnancy could be distinguished from a pregnancy with placental sulphatase deficiency by the presence in the latter of DHAS metabolites. The instrumentation needed regular cleaning and maintenance and was not suitable for processing large numbers of samples.

Liquid chromatography coupled with tandem mass spectrometry (LC-MS-MS) now has the potential for steroid analysis in paediatric samples. Tandem MS is a combination of mass spectrometers to improve analytical performance. More detail about the technology can be found in recent reviews (120). MS coupled with MS (tandem MS) enables sequential filtration, fragmentation and focussing of ions. The collision cell is similar to the quadrupole analysers at MS1 and MS2, so some systems use the term triple quad for a tandem mass spectrometer. Each MS can select specific ions or scan a mass range looking at a spectrum of ions. For quantitative MS, multiple reaction monitoring (MRM) is used. For a description of other modes, see Chace 2009 \# 19 for a review. In an MRM, the first MS (MS1) affords sample purification by selecting an ion of mass to charge for the required analyte. Between the two MS sectors, a collision cell can produce a region for fragmentation of the ion that penetrated the first MS. The second MS (MS2) is set to transmit a fragment ion; characteristic of the analyte can be operated as a 
traditional MS. So in summary, ions are sorted in the first MS, fragmented, then sorted to monitor intensity of ions in second MS. The combination after LC separation thus adds sensitivity and specificity.

In the source, neutral molecules are ionised, then accelerated into the mass analyser. In electrospray, ionisation takes place at atmospheric pressure. A large electrical potential is applied to the metal inlet needle bringing the sample out of the HPLC. As the HPLC effluent liquid leaves the nozzle, the electric field induces a net charge on the small droplets. As the solvent evaporates, the droplet shrinks and the charge density at the surface of the droplet increases. After further evaporation, the droplet explodes and release charged analyte ions. Most androgens and intermediate steroids are measured as positively charged ions; some corticosteroids are measured as negative ions, aldosterone, for example (121). In a few cases, derivatives are formed to assist ionization and assay sensitivity, notably for oestrogens $(122,123)$ and steroid conjugates (124).

Stable isotopes are very useful in a number of ways in clinical investigations and make for ideal internal standards in quantitative MS analysis. A range of stable-isotope labelled steroids are commercially available (Table 3 ). In the LC analysis, the isotopic steroids move slightly faster than the unlabelled analyte; when 5 or more deuterium atoms are included, the two steroids will almost separate, so in effect, the carrier effects of the 2 that protect against system losses can be negated. Due to the natural distributions of isotopes of the elements, all compounds in a mass spectrometer give a cluster of ions, notably at $\mathrm{M}+1$ and $\mathrm{M}+2$ Daltons. If the stable isotope steroids had 2 deuterium atoms, then it effectively is indistinguishable from natural isotopes of the analyte. Ideally, a labelled steroid for use, as an internal standard in MS, should have a mass increment of 3-6 Daltons. Alternatives are isomers and analogues of the analyte that separate from the analyte. High sensitivity methods can be established, because only 2 or 4 ions need to be monitored for an effective analysis with the MS used in ion monitoring mode. The intensities of at least 2 ions from the analyte and 2 ions from the internal standard are recorded with time. A typical set of ions monitored is shown in Table 4. Sensitivity is increased about 500-fold compared with scanning mass range and processing ion signals relevant to the analysis. Response ratios for the ions are as seen in the spectrum. Usually, the most intense ion in the spectrum is used for the quantitative analysis and as described in the GC-MS section, the other ion act as qualifier ion to demonstrate specificity $(125,126)$.

Table 3. Examples of stable isotope labelled steroids

\begin{tabular}{lcc}
\hline & Carbon 13 & Deuterium substitutions \\
\hline Androstenedione & $2,3,4-13 \mathrm{C} 3$ & $2,2,4,6,16,17-\mathrm{d} 7$ \\
Cortisol & & $9,11,11,12-\mathrm{d} 4$ \\
DHA & & $16,16-\mathrm{d} 2$ \\
Testosterone & $3,4-13 \mathrm{C} 2$ & $16,16,17-\mathrm{d} 3$ \\
17-hydroxyprogesterone & & $1,2-\mathrm{d} 2$ \\
11-deoxycortisol & & $21,21-\mathrm{d} 2$ \\
Corticosterone & & $2,2,4,6,6,17,21,21-\mathrm{d} 8$ \\
Aldosterone & & $2,2,4,6,6,17,21,21-\mathrm{d} 8$ \\
\hline
\end{tabular}

Table 4. Typical transitions monitored in LC-MS-MS for steroids

\begin{tabular}{lccc}
\hline & $\begin{array}{c}\mathbf{0 1} \\
\text { Quant (Qual) }\end{array}$ & $\begin{array}{c}\mathbf{0 2} \\
\text { Quant (Qual) }\end{array}$ & Possible interfering steroids \\
\hline Androstenedione (287) & $287.2(287.2)$ & $97.1(189.2)$ & Prednisolone (M + 2) \\
Cortisol (363) & $363.2(363.2)$ & $97.1(121.1)$ & \\
DHA (289) & $271.2(271.2)$ & $213.2(197.2)$ & Hydroxyprogesterones \\
Testosterone (289) & $289.2(289.2)$ & $97.1(109.1)$ & Dihydroxyprogesterones \\
17-hydroxyprogesterone & $331.2(331.2)$ & $97.1(109.1)$ & Dihydroxyprogesterones \\
11-deoxycortisol (347) & $347.2(347.2)$ & $109.1(97.1)$ & $121.1(97.1)$ \\
Corticosterone (347) & $347.2(347.2)$ & $189.2(331.2)$ & \\
Aldosterone & $359.2(359.2)$ & & \\
\hline Stable isotope labelled internal standards will be monitored by separate multiple reaction monitoring (MRM) quantifier and qualifier ions & \\
\hline
\end{tabular}


Steroids can be determined singly in samples or as a profile. This technique will only be described in detail sufficient for clinicians to appreciate what the methods can offer to paediatric endocrine investigations and review the applications to date. Minimal sample preparation is an important advantage, saving time and cost. Protein separation being the simplest first step. The improved specificity of the results leads to more accurate results and new reference ranges will be needed to interpret LC-MS-MS results. Most of the assays are currently at the in-house stage, like when immunoassays were first introduced and results need to be considered carefully. Any abnormal result should be discussed with the laboratory staff, so that problems can be addressed. Interferences can still be encountered and these need to be catalogued, so that the method can be modified to overcome the problem. The equipment manufacturers are exploring options to provide reagent kits for analytes and profiles, so introducing an important level of assay standardisation so desperately needed clinically.

Steroids and vitamin D are being analysed by tandem MS in an increasing number of centres. Assays of steroids in blood, urine and saliva have been reported. As yet there has not been published much by way of QC performance to see if MS/MS is superior to GC-MS where very good precision have been shown by some users as well as poor reproducibility in other tests. Although in principle reference standard methodology is being used (127), the results do not yet meet the requirement one might expected. Reasons for this include matrix affects, procedural differences, calibration differences. The laboratory has an important role to play in the method validation, but there is an obligation for clinicians to alert the laboratory if problems are seen with results out of keeping with the diagnosis.

Despite the apparent simplicity of LC-MS-MS methods, the technique suffers from suppression and enhancement of ionization from compounds co-eluting from the LC into the source of the MS - this is called matrix effect. This can seriously affect the accuracy of the method and requires extensive validation and continuous checking of data to detect interferences. The use of a stable isotope internal standard in most cases, but not all (128-132), will compensate for this, because the chemical similarity with the analyte means both steroids are affected equally. A number of validation experiments are used, such as recovery of standard addition, post-column infusion of standard, and sample dilution (133-136). Since the method looks at mass to charge of a compound and its fragments in the collision cell, then any isomeric steroid will have to be known not to interfere. The isomers will often be separated in the LC. Compounds with the same molecular weight as the analyte are isobaric and have potential for being detected like the analyte $(137,138)$ or internal standard (139). For testosterone, as an example, this required extensive testing (127). Many compounds and especially phospholipids (140-142), are known to interfere in these methods; drugs can also suppress and enhance the signal $(143,144)$. These issues have been reviewed $(145,146)$ and laboratories have the responsibility to consider carefully the matters raised, so will not be debated further in this more clinically orientated review.

In the LC-MS-MS, one can really only look for compounds for which retention times and transitions are known and monitored. By changing MS conditions at intervals over an extended HPLC separation, several steroids can be determined from plasma in one run and there are published reviews in paediatric use (147-150). Several applications of LC-MS-MS profiles cover investigations of $\mathrm{CAH}$, apparent mineralocorticoid excess, aldosteronism, Cushing's syndrome and adrenal insufficiency (151-157) and disorders of sexual development (158-160). Reference ranges for steroids in LC-MS-MS methods will be essential, some have been produced $(155,161,162)$.

LC-MS-MS has also improved confirmation of newborn screening results (163-165). Steroids in urine have also been analysed by LC-MS-MS techniques as free steroids after hydrolysis (166-168) and as conjugates (169). High throughput can be achieved in a number of ways. HPLC with small particles (UPLC) and turbulent flow (170) has speeded up the separation stage; on-line solid phase extraction (171) and column switching (172) are in use. Whatever system is used, the laboratory needs to look out for signs of contamination and carry-over (173).

\section{Bioassays}

Before chemical assays for hormones, the activity could be detected in vivo. Bioassays were insensitive and labour intensive. These tests included for androgens the growth of the capon comb and levator ani muscle, prostate and seminal vesicles of prepubertal rats injected with steroid extracts (174). A number of novel assays look at hormone activity (concentration) in vitro. Steroid activity using primary cells or cell lines that may have been modified genetically are in use. Three types of assay are based on receptor binding, cell proliferation and reporter genes.

A receptor binding assay is like a competitive steroid immunoassay with the antibody replaced by a receptor preparation. The cells may have an endogenous receptor (Cos-7 cells, for example) or cells modified to have a receptor inserted that expresses the receptor protein (MCF-7) (175). The simplest and most sensitive oestrogen assays look at proliferation of MCF-7 cells (E-screen) $(176,177)$. A-screen uses MCF-7 cells transfected with the $A R$ (178). Reporter assays measure the level of expression 
of a steroid dependent reporter gene in response to steroid stimulation. Cell lines and yeast cell strains are transfected with the receptor gene and a reporter gene for an enzyme such as luciferase, beta-galactosidase or chloramphenicol acetyltransferase. When the cells are exposed to ligand, the reporter is activated. A substrate is added and signal detected by luminometry, spectrophotometry or fluorimetry (179). Such assays have been used for androgens in boys (180-182) and oestrogens in girls (183-185). These assays are not yet ready for routine use, but have provided useful information in research settings and in the search for endocrine disrupting chemicals in the environment.

\section{Conclusions}

- Immunoassay has replaced chemical tests of steroids based on colorimetry and will remain important in the field of steroid testing. Some investigations of paediatric problems can be resolved with this technology but is subject to interferences.

- Chromatography can be used before immunoassays to improve specificity, but is too labour intensive for routine use.

- Gas-liquid chromatography with flame ionization and electrochemical detection and high performance LC with UV detection remains useful for measuring steroids at the higher ranges of concentrations in biological fluids (above $100 \mathrm{nmol} / \mathrm{L})$. GC-MS of urinary steroids is an extremely powerful diagnostic tool for defects in adrenal cortical function and will remain important in revealing the nature of steroids in a sample without selection.

- MS is a powerful analytical tool for qualitative and quantitative analysis when coupled with gas and liquid chromatography. MS has been largely used clinically in specialist areas for analysis of steroids alone and in profiles. Tandem mass spectrometry (MS-MS) is becoming more attractive as a routine tool and will bring benefits of new technology to broaden applications.

- LC-MS-MS is often regarded as reference technology. Accuracy and specificity are better than immunoassay, but LC-MS-MS does not yet meet the higher precision standards achieved with GC-MS.

- This review has considered the potential for tandem MS in steroid analysis. Comparisons of results with other methods and results of EQA suggest that LC-MS-MS often shows lower results, but immense performance variation probably through lack of skill, pressure to reduce analytical time, and calibration differences. Manufacturers are working to improve that by developing "kits"-a move that will be well received by clinical laboratories.

- Some progress has been made for peptides, but progress in this area is likely to be slow. Currently, proteins have to be digested to peptide fragments.
- Bioassays are unlikely to compete routinely with immunoassay or MS methods.

- Clinicians should always discuss unusual results with the laboratory, since there may be explanations and alternative investigations that can be analysed by a tandem mass spectrometric approach.

\section{References}

1. Rosner W, Auchus RJ, Azziz R, Sluss PM, Raff H. Position statement: Utility, limitations, and pitfalls in measuring testosterone: an Endocrine Society position statement. J Clin Endocrinol Metab 2007;92:405-413. [Aksstract] / [Full Text] / [PDF]

2. Thienpont LM, Van Uytfanghe K, Blincko S, Ramsay CS, Xie H, Doss RC, Keevil BG, Owen LJ, Rockwood AL, Kushnir MM, Chun KY, Chandler DW, Field HP, Sluss PM. State-of-the-art of serum testosterone measurement by isotope dilution-liquid chromatography-tandem mass spectrometrv. Clin Chem 2008;54:1290-1297. [Abstract] / [Full Text] / [PDF]

3. Sluss PM, Hayes FJ, Adams JM, Barnes W, Williams G, Frost S, Ramp J, Pacenti D, Lehotay DC, George S, Ramsay C, Doss RC, Crowley WF Jr. Mass spectrometric and physiological validation of a sensitive, automated, direct immunoassay for serum estradiol using the Architect. Clin Chim Acta 2008;388:99-105. [Abstract] / [PDF]

4. Vesper HW, Botelho JC, Shacklady C, Smith A, Myers GL. CDC project on standardizing steroid hormone measurements. Steroids 2008;73:1286-1292. [Ábstract] / [PDFI

5. Hoofnagle AN, Wener $\mathrm{MH}$. The fundamental flaws of immunoassays and potential solutions using tandem mass spectrometry. J Immunol Methods 2009;347:3-11. [Abstract] / [PDF]

6. Siekmann L. Requirements for reference (calibration) laboratories in laboratorv medicine. Clin Biochem Rev 2007:28:149-154. [Abstract] / [Full Text] / [PDF]

7. Wudy SA, Wachter UA, Homoki J, Teller WM, Shackleton $\mathrm{CH}$. Androgen metabolism assessment by routine gas chromatography/mass spectrometry profiling of plasma steroids: Part 1, Unconjugated steroids. Steroids 1992;57:319324. [Abstract] / [PDF]

8. Wudy SA, Wachter UA, Homoki J, Teller WM. Determination of dehydroepiandrosterone sulfate in human plasma by gas chromatography/mass spectrometry using a deuterated internal standard: a method suitable for routine clinical use. Horm Res 1993;39:235-240. [Abstract] / [PDF]

9. Wudy SA, Wachter UA, Homoki J, Teller WM. 17 alphahydroxyprogesterone, 4-androstenedione, and testosterone profiled by routine stable isotope dilution/gas chromatographymass spectrometrv in plasma of children. Pediatr Res 1995;38:76-80. [Abstract] / [PDF]

10. Wudy SA, Hartmann M, Homoki J. Hormonal diagnosis of 21-hydroxylase deficiency in plasma and urine of neonates using benchtop gas chromatoaraphv-mass spectrometry. J Endocrinol 2000;165:679-683. [Äbstract] / [PDF]

11. Wudy SA, Hartmann M, Solleder C, Homoki J. Determination of17alpha- hydroxypregnenolone in human plasma by routine isotope dilution mass spectrometry using benchtop gas chromatography-mass selective detection. Steroids 2001;66:759-762. [Abstract] / [PDF]

12. Wudy SA, Hartmann M, Homoki J. Determination of 11-deoxycortisol (Reichstein's compound S) in human plasma by clinical isotope dilution mass spectrometry using benchtop gas chromatographv-mass selective detection. Steroids 2002;67:851-857. [Abstract] / [PDF]

13. Wudy SA, Hartmann MF. Gas chromatography-mass spectrometrv profiling of steroids in times of molecular biology. Horm Metab Res 2004;36:415-422. [Abstract] / [Full Text]/[PDF]

14. Sippell WG, Putz G, Scheuerecker M. Convenient system for the simultaneous separation of 11-deoxycortisol and aldosterone by Sephadex LH-20 multiple column chromatography. J Chromatogr 1978;146:333-336. [Abstract] 
Honour JW

Steroid Assays in Paediatric Endocrinology

15. Sippell WG, Bidlingmaier $F$, Becker $H$, Brünig $T$, Dörr $H$, Hahn H, Golder W, Hollmann G, Knorr D. Simultaneous radioimmunoassay of plasma aldosterone, corticosterone, 11-deoxycorticosterone, progesterone, 17-hydroxyprogesterone,11-deoxycortisol, cortisol and cortisone. J Steroid Biochem 1978;9:63-74. [Abstract]

16. Shackleton $\mathrm{CH}$, Mattox VR, Honour JW. Analysis of intact steroid conjugates by secondary ion mass spectrometry (including FABMS) and by aas chromatography. J Steroid Biochem 1983;19:209-217. [Ábstract]

17. Soldin OP, Sharma H, Husted L, Soldin SJ. Pediatric reference intervals for aldosterone, 17alpha-hydroxyprogesterone, dehydroepiandrosterone, testosterone and 25-hydroxy vitamin D3 using tandem mass spectrometry. Clin Biochem 2009;42:823-827. [Abstract] / [PDF]

18. Concordet D, Geffré A, Braun JP, Trumel C. A new approach for the determination of reference intervals from hospital-based data. Clin Chim Acta 2009;405:43-48. [Abstract] / [PDF]

19. Chace DH. Mass spectrometry in newborn and metabolic screening: historical perspective and future directions. J Mass Spectrom 2009:44:163-170. [Abstract] / [Full Text] / [PDF]

20. Fuqua JS, Sher ES, Migeon CJ, Berkovitz GD. Assay of plasma testosterone during the first six months of life: importance of chromatographic purification of steroids. Clin Chem 1995:41:1146-1149. [Abstract] / [PDF]

21. Stanczyk FZ. Reliability of extraction/chromatography RIAs. Clin Chem 2004;50:778-779. [Abstract] / [Full Text] / [PDF]

22. Stanczyk FZ, Cho MM, Endres DB, Morrison JL, Patel S, Paulson RJ. Limitations of direct estradiol and testosterone immunoassay kits. Steroids 2003;68:1173-1178. [Abstract] / [PDF]

23. Taieb J, Benattar C, Birr AS, Lindenbaum A. Limitations of steroid determination bv direct immunoassay. Clin Chem 2002;48:583-585. [Full Text] / [PDF]

24. Taieb J, Mathian B, Millot F, Patricot MC, Mathieu E, Queyrel N, Lacroix I, Somma-Delpero C, Boudou P. Testosterone measured by 10 immunoassays and by isotope-dilution gas chromatography-mass spectrometry in sera from 116 men women. and children. Clin Chem 2003;49:1381-1395. [Abstract] / [Full Text] / [PDF]

25. Albrecht L, Styne D. Laboratory testing of gonadal steroids in children. Pediatr Endocrinol Rev 2007;5(Suppl 1):599-607. [Abstract]

26. Coucke W, Devleeschouwer N, Libeer JC, Schiettecatte J, Martin M, Smitz J. Accuracy and reproducibility of automated estradiol-17beta and progesterone assays using native serum samples: results obtained in the Belaian external assessment scheme. Hum Reprod 2007;22:3204-3209. [Abstract] / [Full Text] / [PDF]

27. Armbruster DA, Alexander DB. Sample to sample carryover: a source of analytical laboratory error and its relevance to integrated clinical chemistrv/immunoassay systems. Clin Chim Acta 2006:373:37-43. [Ábstract] / [PDF]

28. Khan KS, Dinnes J, Kleijnen J. Systematic reviews to evaluate diagnostic tests. Eur J Obstet Gvnecol Reprod Biol 2001:95:6-11. [Abstract] / [Full Text] / [PDF]

29. Bhasin S, Zhang A, Coviello A, Jasuja R, Ulloor J, Singh R, Vesper $H$, Vasan RS. The impact of assay quality and reference ranges on clinical decision making in the diaanosis of androgen disorders. Steroids 2008;73:1311-1317. [Abstract] / [PDF]

30. Gatti R, Antonelli G, Prearo M, Spinella P, Cappellin E, De Palo EF. Cortisol assays and diagnostic laboratory procedures in human bioloaical fluids. Clin Biochem 2009;42:1205-1217. [Abstract] / [PDE]

31. Vogeser M, Möhnle P, Briegel J. Free serum cortisol: quantification applying equilibrium dialysis or ultrafiltration and an automated immunoassav svstem. Clin Chem Lab Med 2007;45:521-525. [Abstract] / [PDF]

32. Fritz KS, McKean AJ, Nelson JC, Wilcox RB. Analog-based free testosterone test results linked to total testosterone concentrations, not free testosterone concentrations. Clin Chem 2008;54:512-516. [Abstract] / [Full Text] / [PDF]
33. Giton F, Fiet J, Guéchot J, Ibrahim F, Bronsard F, Chopin D, Raynaud JP. Serum bioavailable testosterone: assaved or calculated? Clin Chem 2006;52:474-481. [Abstract] / [Full Text] / [PDF]

34. Van Uytfanghe K, Stöckl D, Kaufman JM, Fiers T, De Leenheer A, Thienpont LM. Validation of 5 routine assays for serum free testosterone with a candidate reference measurement procedure based on ultrafiltration and isotope dilution-gas chromatography-mass spectrometry. Clin Biochem 2005:38:253-261. [Abstract] / [PDF]

35. Swerdloff RS, Wang C. Free testosterone measurement by the analog displacement direct assay: old concerns and new evidence. Clin Chem 2008:54:458-460. [Abstract] / [Full Text] / [PDF]

36. Law CM, Marchant JL, Honour JW, Preece MA, Warner JO. Nocturnal adrenal suppression in asthmatic children taking inhaled beclomethasone dipropionate. Lancet. 1986: 1 (8487): 942-4. Erratum in: Lancet 1987;1(8545):1321. [Abstract] / [PDF]

37. Schäffer L, Luzi F, Burkhardt T, Rauh M, Beinder E. Antenatal betamethasone administration alters stress phvsiologv in healthy neonates. Obstet Gynecol 2009;113:1082-1088. [Abstract] / [Full Text] / [PDF]

38. Bowen RA, Chan $Y$, Ruddel ME, Hortin GL, Csako G, Demosky SJ Jr, Remaley AT. Immunoassay interference by a commonly used blood collection tube additive, the organosilicone surfactant silwet L-720. Clin Chem 2005;51:1874-1882. [Abstract] / [Full Text] / [PDF]

39. Jones $M E$, Folkerd EJ, Doody DA, labal J, Dowsett $M$, Ashworth A, Swerdlow AJ. Effect of delays in processing blood samples on measured endogenous plasma sex hormone levels in women. Cancer Epidemiol Biomarkers Prev 2007;16:1136-1139. [Abstract] / [Full Text] / [PDF]

40. Raff $H$, Sluss PM. Pre-analytical issues for testosterone and estradiol assays. Steroid 2008;73:1297-1304. [Abstract] / [PDF]

41. Zwart SR, Wolf M, Rogers A, Rodgers S, Gillman PL, Hitchcox $\mathrm{K}$, Ericson KL, Smith SM. Stability of analytes related to clinical chemistry and bone metabolism in blood specimens after delayed processing. Clin Biochem 2009;42:907-910. [Abstract] / [PDF]

42. Cetinkaya S, Ozon A, Yordam N. Diagnostic value of salivary cortisol in children with abnormal adrenal cortex functions. Horm Res 2007;67:301-316. [Abstract] / [Full Text] / [PDF]

43. Wood P. Salivary steroid assavs - research or routine? Ann Clin Biochem 2009;46:183-196. Abstract] / [Full Text] / [PDF]

44. Gröschl M. Current status of salivary hormone analysis. Clin Chem 2008;54:1759-1769. [Abstract] / [PDF]

45. Gröschl M, Köhler H, Topf HG, Rupprecht $T$, Rauh M Evaluation of saliva collection devices for the analysis of steroids, peptides and therapeutic drugs. J Pharm Biomed Anal 2008:47:478-486. [Abstract] / [PDF]

46. Kidd S, Midgley P, Lone N, Wallace AM, Nicol M, Smith J, Mclntosh N. A re-investigation of saliva collection procedures that highlights the risk of potential positive interference in cortisol immunoassay. Steroids 2009;74:666-668. [Abstract] / [PDF]

47. Gafni RI, Papanicolaou DA, Nieman LK. Nighttime salivary cortisol measurement as a simple, noninvasive, outpatient screening test for Cushing's syndrome in children and adolescents. J Pediatr 2000:137:30-35. [Abstract] / [Full Text] / [PDF]

48. Raff H. Utility of salivary cortisol measurements in Cushing's syndrome and adrenal insufficiencv. J Clin Endocrinol Metab 2009:94:3647-3655. [Abstract] / [Full Text] / [PDF]

49. Beko G, Varga I, Glaz E, Sereg M, Feldman K, Toth M, Racz K, Patocs A. Cutoff values of midnight salivary cortisol for the diagnosis of overt hypercortisolism are highlv influenced bv methods. Clin Chim Acta 2010;411:364-367. [Abstract] / [PDF]

50. Walker RF, Read GF, Hughes IA, Riad-Fahmy D. Radioimmunoassay of 17 alpha-hydroxyprogesterone in saliva, parotid fluid, and plasma of congenital adrenal hvperplasia patients. Clin Chem 1979;25:542-545. [Abstract] / [PDF]

51. Young MC, Walker RF, Riad-Fahmy D, Hughes IA Androstenedione rhythms in saliva in conaenital adrenal hyperplasia. Arch Dis Child 1988;63:624-628. [Ābstract] / [PDF] 
52. Gray G, Shakerdi L, Wallace AM. Poor specificity and recovery of urinary free cortisol as determined by the Bayer ADVIA Centaur extraction method. Ann Clin Biochem 2003;40:563565. [Abstract] / [PDF]

53. Horie $H$, Kidowaki $T$, Koyama $Y$, Endo T, Homma K, Kambegawa A, Aoki N. Śpecificity assessment of immunoassay kits for determination of urinary free cortisol concentrations. Clin Chim Acta 2007;378:66-70. [Abstract] / [PDF]

54. Wood L, Ducroq DH, Fraser HL, Gillingwater S, Evans $C$, Pickett AJ, Rees DW, John R, Turkes A. Measurement of urinary free cortisol by tandem mass spectrometry and comparison with results obtained by gas chromatographymass spectrometry and two commercial immunoassays. Ann Clin Biochem 2008:45:380-388. [Abstract] / [Full Text] / [PDF]

55. Heckmann M, Hartmann MF, Kampschulte B, Gack H, Bödeker RH, Gortner L, Wudy SA. Cortisol production rates in preterm infants in relation to growth and illness: a noninvasive prospective study using gas chromatography-mass spectrometry. J Clin Endocrinol Metab 2005;90:5737-5742. [Äbstract] / [Full Text] / [PDF]

56. Rahhal SN, Fuqua JS, Lee PA. The impact of assay sensitivity in the assessment of diseases and disorders in children. Steroids 2008;73:1322-1327. [Abstract] / [PDF]

57. Berson SA, Yalow RS. General principles of radioimmunoassav. 1968. (Reprinted) Clin Chim Acta 2006;369:125-143. [Abstract] / [PDF]

58. Ankarberg-Lindgren C, Norjavaara E. A purification step prior to commercial sensitive immunoassay is necessary to achieve clinical usefulness when quantifying serum 17beta-estradiol in prepubertal children. Eur J Endocrinol 2008;158:117-124. [PDF]

59. Schöneshöfer M, Fenner A, Dulce HJ. Assessment of eleven adrenal steroids from a single serum sample by combination of automatic high-performance liquid chromatography and radioimmunoassav (HPLC-RIA)*. J Steroid Biochem 1981;14:377-386. [Abstract]

60. Ueshiba H, Segawa M, Hayashi T, Miyachi Y, Irie M. Serum profiles of steroid hormones in patients with Cushing's syndrome determined bv a new HPLC/RIA method. Clin Chem 1991;37:1329-1333. [Abstract] / [PDF]

61. Eibs G, Schöneshöfer M. Simultaneous determination of fifteen steroid hormones from a single serum sample by highperformance liquid chromatographv and radioimmunoassay. J Chromatogr 1984;310:386-389. [Abstract]

62. Schöneshöfer M, Weber B, Oelkers W, Nahoul K, Mantero F. Urinary excretion rates of 15 free steroids: potential utility in differential diagnosis of Cushing's syndrome. Clin Chem 1986;32:93-96. [Abstract] / [PDF]

63. Golder WA, Sippell WG. Sephadex LH-20 multiple-column chromatography for the simultaneous separation of progesterone, deoxycorticosterone and 17alpha-hydroxyprogesterone from small plasma samples. J Chromatogr 1976;123:293-299. [Abstract]

64. Doerr HG, Versmold HT, Bidlingmaier F, Sippell WG. Adrenocortical steroids in small-for-gestational-age term infants during the earlv neonatal period. Pediatr Res 1989;25:115-118. [Abstract] / [PDF]

65. Riepe FG, Wonka S, Partsch CJ, Sippell WG. Automated chromatographic system for the simultaneous measurement of plasma pregnenolone and 17-hydroxypregnenolone by radioimmunoassav. J Chromatogr B Biomed Sci Appl 2001;763:99-106. [Abstract] / [PDF]

66. Milewicz $A$, Vecsei $P$, Korth-Schütz $S$, Haack $D$, Rösler $A$ Lichtwald K, Lewicka S, von Mittelstaedt G. Development of plasma 21-deoxycortisol radioimmunoassay and application to the diagnosis of patients with 21-hvdroxvlase deficiency. J Steroid Biochem 1984;21:185-191. [Ábstract]

67. Giton F, Guéchot J, Fiet J. New reusable Celite/ethylene glycol cartridges for selective chromatography of steroids before immunoassay. Clin Biochem 2009;42:1735-1738. [Abstract] / [PDF]

68. Kreutzmann DJ, Silink M, Cam GR. Celite multi-column chromatography for the simultaneous separation of progesterone, deoxycorticosterone and 17 alpha-hydroxyprogesterone from small plasma or tissue samples. J Chromatogr 1982;228:95-101. [Abstract] / [PDF]
69. Morineau G, Gosling J Patricot MC, Soliman $\mathrm{H}$, Boudou $\mathrm{P}$, al Halnak A, Le Brun G, Brérault JL, Julien R, Villette JM, Fiet J. Convenient chromatographic prepurification step before measurement of urinary cortisol by radioimmunoassay. Clin Chem 1997;43:786-793. [Abstract] / [Full Text] / [PDF]

70. Fenske M. Clean-up and re-use of kieselguhr (Extrelut) for liquid-liquid extraction of urinary cortisol. J Chromatogr B Biomed Sci Appl 1997;692:238-240. [Abstract] / [PDF]

71. Nahoul K, Patricot MC, Moatti JP, Revol A. Determination of urinary cortisol with three commercial immunoassavs. J Steroid Biochem Mol Biol 1992:43:573-580. [Abstract] / [PDF]

72. Apter D, Jänne $O$, Vihko R. Lipidex chromatography in the radioimmunoassay of serum and urinary cortisol. Clin Chim Acta 1975;63:139-148. [Abstract] / [PDF]

73. Apter $D$, Jánne $O$, Karvonen $P$, Vihko R. Simultaneous determination of five sex hormones in human serum by radioimmunoassay after chromatography on Lipidex-5000. Clin Chem 1976;22:32-38. [Abstract]

74. Wu AH. A selected history and future of immunoassay development and applications in clinical chemistry. Clin Chim Acta 2006;369:119-124. [Abstract] / [PDF]

75. Wallace AM, Beesley J, Thomson M, Giles CA, Ross AM, Taylor NF. Adrenal status during the first month of life in mature and premature human infants. J Endocrinol 1987:112:473-480. [Abstract] / [PDF]

76. Tonetto-Fernandes $\mathrm{V}$, Lemos-Marini $\mathrm{SH}$, Kuperman $\mathrm{H}_{\text {, }}$ Ribeiro-Neto LM, Verreschi IT, Kater CE. Serum 21-Deoxycortisol, 17-Hydroxyprogesterone, and 11-deoxycortisol in classic congenital adrenal hyperplasia: clinical and hormonal correlations and identification of patients with 11 betahydroxylase deficiency among a large group with alleged 21-hydroxylase deficiencv. J Clin Endocrinol Metab 2006;91:2179-2184. [Abstract] / [Full Text] / [PDF]

77. Stoks PG, Benraad TJ. Rapid separation of plasma steroids by reversed-phase high-performance liquid chromatography with timed collection of fractions. J Chromatogr 1983;276:408-412. [Abstract]

78. Hunter WM. Radioimmunoassay and saturation analysis. Preparation and assessment of radioactive tracers. Br Med Bull 1974;30:18-23. [Abstract]

79. Wong T, Shackleton $\mathrm{CH}$, Covey TR, Ellis G. Identification of the steroids in neonatal plasma that interfere with 17 alphahydroxyprogesterone radioimmunoassays. Clin Chem 1992;38:1830-1837. [Abstract] / [PDF]

80. Ratcliffe WA, McClure JP, Auld WH, Honour JW, Fraser R, Ratcliffe JG. Precocious pseudopuberty due to a rare form of congenital adrenal hyperplasia. Biochemical investigation and pitfalls in interpretation of hormone assays. Ann Clin Biochem 1982;19:145-150. [Abstract]

81. Brossaud J, Barat P, Gualde D, Corcuff JB. Cross reactions elicited by serum 17-OH progesterone and 11-desoxvcortisol in cortisol assays. Clin Chim Acta 2009:407:72-74. [Abstract] / [PDF]

82. Chong $H$, Cheah SH, Ragavan $M$, Johgalingam VT. Development of an indirect enzyme immunoassay using monoclonal antibodies for the measurement of 17alphahydroxyprogesterone in human serum. J Immunoassay Immunochem 2009;30:166-179. [Abstract] / [Full Text] / [PDF]

83. Lewis JG, Bason LM, Elder PA. Production and characterization of monoclonal antibodies to dehydroepiandrosterone sulfate: application to direct enzyme-linked immunosorbent assays of dehydroepiandrosterone sulfate and androsterone/epiandrosterone sulfates in plasma. Steroids 1996:61:682-687. [Abstract] / [PDF]

84. Lewis JG, Manley L, Whitlow JC, Elder PA. Production of a monoclonal antibody to cortisol: application to a direct enzyme-linked immunosorbent assay of plasma. Steroids 1992;57:82-85. [Abstract] / [PDF]

85. Kobayashi N, Sun P, Fujimaki Y, Niwa T, Nishio T, Goto J, Hosoda $\mathrm{H}$. Generation of a novel monoclonal antibody against cortisol-[C-4]-bovine serum albumin conjugate: application to enzyme-linked immunosorbent assay for urinary and serum cortisol. Anal Sci 2002;18:1309-1314. [Abstract]

86. Mares A, De Boever J, Osher J, Quiroga S, Barnard G, Kohen F. A direct non-competitive idiometric enzyme immunoassay for serum oestradiol. J Immunol Methods 1995;181:83-90. [Abstract] / [PDF] 
Honour JW

Steroid Assays in Paediatric Endocrinology

87. Niwa T, Kobayashi T, Sun P, Goto J, Oyama H, Kobayashi N An enzyme-linked immunometric assay for cortisol based on idiotype-anti-idiotvpe reactions. Anal Chim Acta 2009;638:94100. [Abstract] / [PDF]

88. Koshida S, Asanuma K, Kuribayashi K, Goto M, Tsuji N, Kobayashi D, Tanaka M,Watanabe N. Prevalence of human anti-mouse antibodies (HAMAs) in routine examinations. Clin Chim Acta 2010;411:391-394. [Abstract] / [PDF]

89. Saleem M, Lewis JG, Florkowski CM, Mulligan GP, George PM, Hale P. A patient with pseudo-Addison's disease and falsely elevated thyroxine due to interference in serum cortisol and free thyroxine immunoassays by two different mechanisms. Ann Clin Biochem 2009:46:172-175. [Abstract] / [Full Text] / [PDF]

90. Ismail AA. Interference from endogenous antibodies in automated immunoassays: what laboratorians need to know. J Clin Pathol 2009;62:673-678. [Abstract] / [Full Text] / [PDF]

91. Dimeski G. Interference testina. Clin Biochem Rev 2008:29 (Suppl 1):S43-48. [Abstract] / [Füll Text] / [PDF]

92. Schall RF Jr, Tenoso HJ. Alternatives to radioimmunoassay: labels and methods. Clin Chem 1981:27:1157-1164. [Abstract] / [PDF

93. Wheeler MJ. Automated immunoassav analysers. Ann Clin Biochem 2001;38:217-229. [Abstract] / [PDF]

94. Tomlinson C, Macintyre H, Dorrian CA, Ahmed SF, Wallace AM. Testosterone measurements in early infancy. Arch Dis Child Fetal Neonatal Ed 2004;89:F558-F559. [Abstract] / [PDF]

95. Wan B, Augustin R, Chan MK, Leblond J, Verjee Z, Adeli K. Analytical performance and workflow evaluation of the Roche E170 modular immunoassay analvzer in a pediatric setting. Clin Biochem 2005;38:262-271. [Abstract] / [PDF]

96. Chan MK, Seiden-Long I, Aytekin M, Quinn F, Ravalico T, Ambruster D, Adeli K. Canadian Laboratory Initiative on Pediatric Reference Interval Database (CALIPER): pediatric reference intervals for an integrated clinical chemistry and mmunoassay analyzer, Abbott ARCHITECT ci8200. Clin Biochem 2009:42:885-891. [Abstract] / [PDF]

97. Watson ID, Lawton K. Wrong biochemistry results Companies and Medical Devices Agency must act to prevent wrong results. BMJ 2002;324:422-423. [Abstract] / [PDF

98. Warner $\mathrm{MH}$, Kane JW, Atkin SL, Kilpatrick ES. Dehydroepiandrosterone sulphate interferes with the Abbott Architect direct immunoassav for testosterone. Ann Clin Biochem 2006;43:196-199. [Abstract] / [PDF]

99. Tomlinson C, Wallace AM, Ahmed SF. Erroneous testosterone assay causing diagnostic confusion in a newborn infant with intersex anomalies. Acta Paediatr 2004;93:10041005. [Abstract] / [Full Text] / [PDF]

100. Bay K, Andersson AM, Skakkebaek NE. Estradiol levels in prepubertal boys and girls-analvtical challenges. Int $\mathrm{J}$ Andro 2004;27:266-273. [ Abstract] / [Full Text] / [PD̄F]

101. Honour JW. Urinary steroid profile analysis. Clin Chim Acta 2001;313:45-50. [Abstract] / [PDF]

102. Caulfield MP, Lynn T, Gottschalk ME, Jones KL, Taylor NF Malunowicz EM, Shackleton $\mathrm{CH}$, Reitz RE, Fisher DA. The diagnosis of congenital adrenal hyperplasia in the newborn by gas chromatography/mass spectrometry analysis of random urine specimens. J Clin Endocrinol Metab 2002;87:36823690. [Abstract] / [Full Text] / [PDF]

103. Jerjes WK, Cleare AJ, Wood PJ, Taylor NF. Assessment of subtle changes in glucocorticoid negative feedback using prednisolone: comparison of salivary free cortisol and urinary cortisol metabolites as endpoints. Clin Chim Acta 2006;364:279-286. [Abstract] / [PDF]

104. Christakoudi S, Cowan DA, Taylor NF. Steroids excreted in urine by neonates with 21-hydroxylase deficiency: characterization, using GC-MS and GC-MS/MS, of the D-ring and side chain structure of preananes and pregnenes. Steroids 2010:75:34-52. [Abstract] / [PDF]

105. Heckmann M, Hartmann MF, Kampschulte B, Gack $H$ Bödeker RH, Gortner L, Wudy SA. Assessing cortisol production in preterm infants: do not dispose of the nappies. Pediatr Res 2005;57:412-418. [Abstract] / [PDF]

106. Remer T, Maser-Gluth C, Wudy SA. Glucocorticoid measurements in health and disease--metabolic implications and the potential of 24-h urine analyses. Mini Rev Med Chem 2008;8:153-170. [Abstract] / [PDF]
107. Courant F, Aksglaede L, Antignac JP Monteau F, Sorensen $\mathrm{K}$, Andersson AM, Skakkebaek NE, Juul A, Bizec BL. Assessment of circulating sex steroid levels in prepubertal and pubertal boys and girls by a novel ultrasensitive gas chromatography-tandem mass spectrometry method. J Clin Endocrinol Metab 2010;95:82-92. [Abstract] / [Full Text] / [PDF]

108. Fink RS, Pierre LN, Daley-Yates PT, Richards DH, Gibson A Honour JW. Hypothalamic-pituitary-adrenal axis function after inhaled corticosteroids: unreliability of urinary free cortisol estimation. J Clin Endocrinol Metab 2002:87:4541-4546. [Abstract] / [Full Text] / [PDF]

109. Darney KJ Jr, Wing TY, Ewing LL. Simultaneous measurement of four testicular delta 4-3-ketosteroids by isocratic high-performance liquid chromatography with on-line ultraviolet absorbance detection. J Chromatogr 1983;257:81-90. [Abstract] / [PDF]

110. Wei JQ, Zhou XT, Wei JI. Simultaneous measurement of eight corticosteroids by liquid chromatography, and application of the procedure to diagnosis of conaenital adrenal hyperplasia. Clin Chem 1987;33:1354-1359. [Abstract] / [PDF]

111. Wei JQ, Wei JL, Zhou XT, Cheng JP. Isocratic reversed phase high performance liquid chromatography determination of twelve natural corticosteroids in serum with on-line ultraviolet and fluorescence detection. Biomed Chromatogr 1990;4:161164. [Abstract] / [PDF]

112. Wei JQ, Wei JL, Lucarelli C, Zhou XT, Wang DQ, Dai WJ, Li S, Li SM, Liu RT. Serum steroid hormonal profiles by reversed-phase liquid chromatography in patients with 17-hydroxylase deficiency and in an affected family. Clin Chem 1992;38:76-82. [Abstract] / [PDF]

113. Wei JQ, Wei JL, Li WC, Bi YS, Wei FC. Genotyping of five chinese patients with 17alpha-hydroxylase deficiency diagnosed through high-performance liquid chromatography serum adrenal profile: identification of two novel CYP17 mutations. J Clin Endocrinol Metab 2006;91:3647-3653. [Abstract] / [Full Text] / [PDF]

114. Turpeinen $U$, Markkanen $H$, Välimäki $M$, Stenman $U H$. Determination of urinarv free cortisol bv HPLC. Clin Chem 1997:43:1386-1391. [Abstract] / [Full Text] / [PDF]

115. De Palo EF, Antonelli G, Benetazzo A, Prearo M, Gatti R. Human saliva cortisone and cortisol simultaneous analysis using reverse phase HPLC technique. Clin Chim Acta 2009:405:60-65. [Abstract] / [PDF]

116. Kenny FM, Malvaux P, Migeon CJ. Cortisol production rate in newborn babies, older infants. and children. Pediatrics 1963:31:360-373. [Abstract] / [PDF]

117. Esteban NV, Yergey AL. Cortisol production rates measured by liquid chromatoaraphy/mass spectrometry. Steroids 1990:55:152-158. [Abstract] / [PDF]

118. Wudy SA, Hartmann M, Svoboda M. Determination of 17-hydroxyprogesterone in plasma by stable isotope dilution/benchtop liauid chromatoaraphv-tandem mass spectrometry. Horm Res 2000;53:68-71. [Abstract] / [Full Text] / [PDF]

119. Shackleton $\mathrm{CH}$, Straub KM. Direct analysis of steroid conjugates: the use of secondary ion mass spectrometry. Steroids 1982;40:35-51. [Abstract] / [PDF]

120. Pitt JJ. Principles and applications of liquid chromatographymass spectrometrv in clinical biochemistrv. Clin Biochem Rev 2009;30:19-34. [Abstract] / [Full Text] / [PDF]

121. Taylor PJ, Cooper DP, Gordon RD, Stowasser M. Measurement of aldosterone in human plasma by semiautomated HPLC-tandem mass spectrometrv. Clin Chem 2009;55:1155-1162. [Abstract] / [Full Text] / [PDF́]

122. Singh G, Gutierrez A, Xu K, Blair IA. Liquid chromatography/ electron capture atmospheric pressure chemical ionization/ mass spectrometry: analysis of pentafluorobenzyl derivatives of biomolecules and druas in the attomole ranae. Anal Chem 2000:72:3007-3013. [Abstract] / [Full Text] / [PDF]

123. Kushnir MM, Rockwood AL, Bergquist J, Varshavsky M, Roberts WL, Yue B, Bunker AM, Meikle AW. High-sensitivity tandem mass spectrometry assay for serum estrone and estradiol. Am J Clin Pathol 2008:129:530-539. [Abstract] / [PDF] 
Honour JW

Steroid Assays in Paediatric Endocrinology

124. Penning TM, Lee $S H$, Jin $Y$, Gutierrez A, Blair IA. Liquid chromatography-mass spectrometry (LC-MS) of steroid hormone metabolites and its applications. J Steroid Biochem Mol Biol 2010 Jan 18. [Evub ahead of print] PubMed PMID: 20083198. [Abstract] / [PDF]

125. Kushnir MM, Rockwood AL, Nelson GJ, Yue B, Urry FM. Assessing analytical specificity in quantitative analysis using tandem mass spectrometry. Clin Biochem 2005; 38: 319-327.

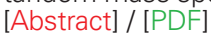

126. Kushnir MM, Rockwood AL, Bergquist J. Liquid chromatographytandem mass spectrometry applications in endocrinology. Mass Spectrom Rev 2009 Aug 25. [Epub ahead of print] PubMed PMID: 19708015. [Abstract] / [Full Text] / [PDF]

127. Tai SS, Xu B, Welch MJ, Phinney KW. Development and evaluation of a candidate reference measurement procedure for the determination of testosterone in human serum using isotope dilution liquid chromatography/tandem mass spectrometry. Anal Bioanal Chem 2007;388:1087-1094. [Abstract] / [Full Text] / [PDF]

128. Shi G. Application of co-eluting structural analog internal standards for expanded linear dynamic range in liquid chromatoaraphv/electrosprav mass spectrometrv. Rapid Commun Mass Spectrom 2003;17:202-206. [Abstract] / [Full Text] / [PDF]

129. Sleno L, Volmer DA. Assessing the properties of internal standards for quantitative matrix-assisted laser desorption ionization mass spectrometry of small molecules. Rabid Commun Mass Spectrom 2006;20:1517-1524. [Abstract] / [Full Text] / [PDF]

130. Jemal M, Schuster A, Whigan DB. Liquid chromatography/ tandem mass spectrometry methods for quantitation of mevalonic acid in human plasma and urine: method validation, demonstration of using a surrogate analyte, and demonstration of unacceptable matrix effect in spite of use of a stable isotope analog internal standard. Rapid Commun Mass Spectrom 2003;17:1723-1734. [Abstract] / [Full Text] / [PDF]

131. Jemal M, Ouyang Z, Xia YQ. Systematic LC-MS/MS bioanalytical method development that incorporates plasma phospholipids risk avoidance, usage of incurred sample and well thought-out chromatoaraphy. Biomed Chromatogr 2010;24:2-19. [Abstract] / [PDF]

132. Stokvis $\mathrm{E}$, Rosing $\mathrm{H}$, Beijnen $\mathrm{JH}$. Stable isotopically labeled internal standards in quantitative bioanalysis using liquid chromatography/mass spectrometrv: necessitv or not? Rapid Commun Mass Spectrom 2005;19:401-407. [Abstract] / [Full Text] / [PDF]

133. Matuszewski BK, Constanzer ML, Chavez-Eng CM Strategies for the assessment of matrix effect in quantitative bioanalytical methods based on HPLC-MS/MS. Anal Chem 2003;75:3019-3030. [Abstract] / [Full Text] / [PDF]

134. Chambers E, Wagrowski-Diehl DM, Lu Z, Mazzeo JR Systematic and comprehensive strategy for reducing matrix effects in LC/MS/MS analyses. J Chromatoar B Analyt Technol Biomed Life Sci 2007;852:22-34. [Abstract] / [PDF]

135. Heller DN. Ruggedness testing of quantitative atmospheric pressure ionization mass spectrometry methods: the effect of co-injected matrix on matrix effects. Rapid Commun Mass Spectrom 2007:21:644-652. [Abstract] / [Full Text] / [PDF]

136. Van Eeckhaut A, Lanckmans K, Sarre S, Smolders I, Michotte Y. Validation of bioanalytical LC-MS/MS assays: evaluation of matrix effects. J Chromatoar B Analyt Technol Biomed Life Sci 2009:877:2198-21207. [Äbstract] / [PDF]

137. Kushnir MM, Rockwood AL, Nelson GJ. Simultaneous quantitative analysis of isobars by tandem mass spectrometry from unresolved chromatoaraphic peaks. J Mass Spectrom 2004;39:532-540. [Abstract] / [Full Text] / [PDF]

138. Yan Z, Maher N, Torres R, Cotto C, Hastings B, Dasgupta M Hyman R, Huebert N, Caldwell GW. Isobaric metabolite interferences and the requirement for close examination of raw data in addition to stringent chromatographic separations in liquid chromatography/tandem mass spectrometric analysis of drugs in biological matrix. Rapid Commun Mass Spectrom 2008:22:2021-2028. [Abstract] / [Full Text] / [PDF]
139. Duxbury K, Owen L, Gillingwater S, Keevil B. Naturally occurring isotopes of an analyte can interfere with doubly deuterated internal standard measurement. Ann Clin Biochem 2008:45:210-212. [Abstract] / [Full Text] / [PDF]

140. Keller BO, Sui J, Young AB, Whittal RM. Interferences and contaminants encountered in modern mass spectrometry. Anal Chim Acta 2008;627:71-81. [Abstract] / [PDF̈]

141. Little JL, Wempe MF, Buchanan CM. Liquid chromatographymass spectrometry/mass spectrometry method development for drug metabolism studies: Examining lipid matrix ionization effects in plasma. J Chromatoar B Analvt Technol Biomed Life Sci 2006;833:219-230. [Abstract] / [PDF]

142. Ismaiel OA, Halquist MS, Elmamly MY, Shalaby A, Thomas Karnes $\mathrm{H}$. Monitoring phospholipids for assessment of ion enhancement and ion suppression in ESI and APCI LC/MS/MS for chlorpheniramine in human plasma and the importance of multiple source matrix effect evaluations. $J$ Chromatogr B Analvt Technol Biomed Life Sci 2008;875:333-343. [Abstract] / [PDF]

143. Srinivas NR. Dodging matrix effects in liquid chromatography tandem mass spectrometric assays--compilation of key learnings and perspectives. Biomed Chromatogr 2009;23:451-454. [A'bstract] / [PDF]

144. Leverence R, Avery MJ, Kavetskaia O, Bi H, Hop CE, Gusev Al. Signal suppression/enhancement in HPLC-ESI-MS/MS from concomitant medications. Biomed Chromatogr 2007;21:1143-1150. [Abstract] / [PDF]

145. Annesley TM. Ion suppression in mass spectrometrv. Clin Chem 2003;49:1041-1044. [Abstract] / [Full Text] / [PDF]

146. Kruve A, Leito I, Herodes K. Combating matrix effects in LC/ESI/MS: the extrapolative dilution approach. Anal Chim Acta 2009;651:75-80. [Abstract] / [PDF]

147. Vogeser M, Parhofer KG. Liquid chromatography tandemmass spectrometry (LC-MS/MS)--technique and applications in endocrinology. Exp Clin Endocrinol Diabetes 2007;115:559570. [Abstract] / [Fuli Text] / [PDF]

148. Rauh M. Steroid measurement with LC-MS/MS in pediatric endocrinoloav. Mol Cell Endocrinol 2009;301:272-281. [Abstract] / [P̄DF]

149. Rauh M. Steroid measurement with LC-MS/MS. Application examples in pediatrics. J Steroid Biochem Mol Biol 2009 Dec 28. [Epub ahead of print] [Abstract] / [PDF]

150. Kushnir MM, Rockwood AL, Bergquist J. Liquid chromatographytandem mass spectrometry applications in endocrinology. Mass Spectrom Rev 2009 Aua 25. [Epub ahead of print] PubMed PMID: 19708015. [Abstract] / [Full Text] / [PDF]

151. Minutti CZ, Lacey JM, Magera MJ, Hahn SH, McCann M, Schulze A, Cheillan D, Dorche C, Chace DH, Lymp JF', Zimmerman D, Rinaldo P, Matern D. Steroid profiling by tandem mass spectrometry improves the positive predictive value of newborn screening for congenital adrenal hvperplasia. J Clin Endocrinol Metab 20004:89:36̆87-3693. [Abstract] / [Full Text] / [PDF]

152. Guo T, Taylor RL, Singh RJ, Soldin SJ. Simultaneous determination of 12 steroids by isotope dilution liquid chromatography-photospray ionization tandem mass spectrometry. Clin Chim Acta 2006;372:76-82. [Abstract] / [PDF]

153. Holst JP Soldin SJ, Tractenberg RE, Guo T Kundra P, Verbalis JG, Jonklaas J. Use of steroid profiles in determining the cause of adrenal insufficiency. Steroids 2007;72:71-84. [Abstract] / [PDF]

154. Ceglarek U, Kortz L, Leichtle A, Fiedler GM, Kratzsch J, Thiery $J$. Rapid quantification of steroid patterns in human serum by on-line solid phase extraction combined with liquid chromatography-triple quadrupole linear ion trap mass spectrometry. Clin Chim Acta 2009;401:114-118. [Abstract] / [PDF]

155. Soldin OP, Sharma H, Husted L, Soldin SJ. Pediatric reference intervals for aldosterone, 17alpha-hydroxyprogesterone, dehydroepiandrosterone, testosterone and 25-hydroxy vitamin D3 using tandem mass spectrometry. Clin Biochem 2009:42:823-827. [Abstract] / [PDF]

156. Soldin SJ, Soldin OP. Steroid hormone analysis by tandem mass spectrometry. Clin Chem 2009;55:1061-1066. [Abstract] / [Full Text] / [PDF] 
Honour JW

Steroid Assays in Paediatric Endocrinology

157. Rossi C Calton L, Hammond G, Brown HA Wallace AM Sacchetta P, Morris M. Serum steroid profiling for Congenital Adrenal Hyperplasia using liquid chromatography-tandem mass spectrometry. Clin Chim Acta 2010:411:222-228. [Abstract] / [PDF]

158. Janzen N, Peter $M$, Sander $S$, Steuerwald U, Terhardt $M$ Holtkamp U, Sander J. Newborn screening for congenital adrenal hyperplasia: additional steroid profile using liquid chromatography-tandem mass spectrometry. J Clin Endocrinol Metab 2007;92:2581-2589. [Abstract] / [Full Text] / [PDF]

159. Janzen N, Sander S, Terhardt M, Peter M, Sander J. Fast and direct quantification of adrenal steroids by tandem mass spectrometry in serum and dried blood spots. J Chromatogr B Analvt Technol Biomed Life Sci 2008;861:117-122. [Abstract] / [PDF]

160. Schwarz E, Liu A, Randall H, Haslip C, Keune F, Murray M, Longo $N$, Pasquali $M$. Use of steroid profiling by UPLCMS/MS as a second tier test in newborn screening for congenital adrenal hyperplasia: the Utah experience. Pediatr Res 2009:66:230-235. [Abstract] / [Full Text] / [PDF]

161. Gallagher LM, Owen LJ, Keevil BG. Simultaneous determination of androstenedione and testosterone in human serum by liquid chromatography-tandem mass spectrometry. Ann Clin Biochem 2007:44:48-56. [Abstract] / [PDF]

162. Shiraishi S, Lee PW, Leung A, Goh VH, Swerdloff RS, Wang C. Simultaneous measurement of serum testosterone and dihydrotestosterone by liquid chromatography-tandem mass spectrometry. Clin Chem 2008;54:1855-1863. [Abstract] / [PDF]

163. Wang C Shiraishi S, Leung A Baravarian S, Hull L, Goh V Lee PW, Swerdloff RS. Validation of a testosterone and dihydrotestosterone liquid chromatography tandem mass spectrometry assay: Interference and comparison with established methods. Steroids 2008;73:1345-1352. [Abstract] / [PDF]

164. Yamashita K, Nakagawa R, Okuyama M, Honma S, Takahashi M. Numazawa M. Simultaneous determination of tetrahydrocortisol, allotetrahydrocortisol and tetrahydrocortisone in human urine by liquid chromatography-electrospray ionization tandem mass spectrometry. Steroids 2008;73:727-737. [Abstract] / [PDF]

165. Cuzzola A, Petri A, Mazzini F, Salvadori P. Application of hyphenated mass spectrometry techniques for the analysis of urinary free glucocorticoids. Rapid Commun Mass Spectrom 2009 23:2975-2982. [Abstract] / [Full Text] / [PDF]

166. Cho HJ, Kim JD, Lee WY, Chung BC, Choi MH. Quantitative metabolic profiling of 21 endogenous corticosteroids in urine by liquid chromatography-triple quadrupole-mass spectrometry. Anal Chim Acta 2009;632:101-108. [Äbstract] / [PंDF]

167. Ikegawa S, Hasegawa M, Okihara R, Shimidzu C, Chiba $H$ lida T. Mitamura K. Simultaneous determination of twelve tetrahydrocorticosteroid glucuronides in human urine by liquid chromatographv/electrosprav ionization-linear ion trap mass spectrometrv. Anal Chem 2009;81:10124-10135. [Abstract] / [Full Text] / [PDF]

168. Salameh WA, Redor-Goldman MM, Clarke NJ, Reitz RE, Caulfield MP. Validation of a total testosterone assay using high-turbulence liquid chromatography tandem mass spectrometry: total and free testosterone reference ranges. Steroids 2010;75:169-175. [Abstract] / [PDF]

169. Saba A, Raffaelli A, Cupisti A, Petri A, Marcocci C, Salvadori $P$. Recent advances in the assessment of the ratios of cortisol to cortisone and of some of their metabolites in urine bv LC-MS-MS. J Mass Spectrom 2009;44:541-548. [Abstract] / [Full Text]

170. Borrey D, Moerman E, Cockx A, Engelrelst V, Langlois MR. Column-switching LC-MS/MS analysis for quantitative determination of testosterone in human serum. Clin Chim Acta 2007;382:134-137. [Abstract] / [PDF]
171. Hughes NC, Wong EY, Fan J, Bajaj N. Determination of carryover and contamination for mass spectrometry-based chromatographic assays. AAPS J 2007;9:E353-360. [PDF]

172. Meikle AW, Kushnir MM, Rockwood AL, Pattison EG, Terry AH, Sandrock T, Bunker AM, Phanslkar AR, Owen WE, Roberts WL. Adrenal steroid concentrations in children seven to seventeen years of aqe. J Pediatr Endocrinol Metab 2007;20:1281-1291. [Abstract] / [Full Text]

173. Garagorri JM, Rodr'guez G, Lario-Elboj AJ, Olivares JL, LarioMuñoz A, Orden I. Reference levels for 17-hydroxyprogesterone, 11-desoxycortisol cortisol, testosterone, dehydroepiandrosterone sulfate and androstenedione in infants from birth to six months of age. Eur $\mathrm{J}$ Pediatr 2008;167:647-653. [Abstract] / [Full Text] / [PDF]

174. Hershberger LG, Shipley EG, Meyer RK. Myotrophic activity of 19-nortestosterone and other steroids determined by modified levator ani muscle method. Proc Soc Exp Biol Med 1953;83:175-180. [Abstract]

175. Sonneveld E, Jansen HJ, Riteco JA, Brouwer A, van der Burg B. Development of androgen- and estrogen-responsive bioassays, members of a panel of human cell line-based highly selective steroid-responsive bioassays. Toxicol Sci 2005;83:136-148. [Abstract] / [Full Text] / [PDF]

176. Sonnenschein C, Szelei J, Nye TL, Soto AM. Control of cell proliferation of human breast MCF7 cells; serum and estrogen resistant variants. Oncol Res 1994;6:373-381. [Abstract]

177. Rasmussen TH, Nielsen F, Andersen HR, Nielsen JB, Weihe P, Grandjean P. Assessment of xenoestrogenic exposure by a biomarker approach: application of the E-Screen bioassay to determine estrogenic response of serum extracts. Environ Health 2003;2:12. [Abstract] / [Full Text] / [PDF]

178. Szelei J, Jimenez J, Soto AM, Luizzi MF, Sonnenschein C. Androgen-induced inhibition of proliferation in human breast cancer MCF7 cells transfected with androgen receptor. Endocrinology 1997;138:1406-1412. [Abstract] / [Full Text] / [PDF]

179. Roy P, Salminen H, Koskimies P, Simola J, Smeds A, Saukko $P$, Huhtaniemi IT. Screening of some anti-androgenic endocrine disruptors using a recombinant cell-based in vitro bioassay. J Steroid Biochem Mol Biol 2004;88:157-166. [Abstract] / [PDF]

180. Raivio T, Palvimo JJ, Dunkel L, Wickman S, Jänne OA. Novel assay for determination of androgen bioactivity in human serum. J Clin Endocrinol Metab 2001:86:1539-1544. [Abstract] / [Full Text] / [PDF]

181. Roy P, Franks S, Read M, Huhtaniemi IT. Determination of androgen bioactivity in human serum samples using a recombinant cell based in vitro bioassav. J Steroid Biochem Mol Biol 2006:101:68-77. [Abstract] / [PDF]

182. Bovee TF, Lommerse JP, Peijnenburg AA, Fernandes EA, Nielen MW. A new highly androgen specific yeast biosensor, enabling optimisation of (Q)SAR model approaches. J Steroid Biochem Mol Biol 2008;108:121-131. [Abstract] / [PDF]

183. Klein KO, Baron J, Barnes KM, Pescovitz OH, Cutler GB Jr. Use of an ultrasensitive recombinant cell bioassay to determine estrogen levels in girls with precocious puberty treated with a luteinizing hormone-releasing hormone agonist. J Clin Endocrinol Metab 1998;83:2387-2389. [Abstract] / [Full Text] / [PDF]

184. Klein KO, Baron J, Colli MJ, McDonnell DP, Cutler GB Jr. Estrogen levels in childhood determined by an ultrasensitive recombinant cell bioassay. J Clin Invest 1994;94:2475-2480. [Abstract] / [PDF]

185. Garrett SD, Lee HA, Morgan MR. A nonisotopic estrogen receptor-based assay to detect estroqenic compounds. Nat Biotechnol 1999;17:1219-1222. [Abstract] / [Full Text] / [PDF] 